BNL- 64932

Informal Report

\title{
MATERIALS TESTING FOR IN SITU STABILIZATION TREATABILITY STUDY OF INEEL MIXED WASTE SOILS
}

John Heiser and Mark Fuhrmann

\section{RECEIVED \\ DEC 181997 \\ OSTI}

September 1997

\section{ENVIRONMENTAL \& WASTE TECHNOLOGY CENTER DEPARTMENT OF ADVANCED TECHNOLOGY BROOKHAVEN NATIONAL LABORATORY, ASSOCIATED UNIVERSITIES, INC. \\ P.O. BOX 5000, UPTON, NEW YORK 11973-5000}




\section{Materials Testing for In Situ Stabilization Treatability Study of INEEL Mixed Waste Soils}

September 1997

Prepared by:

John Heiser

Mark Fuhrmann

Environmental \& Waste Technology Center

Brookhaven National Laboratory

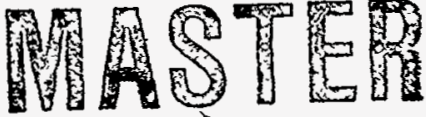

Upton, New York

DERTRBUTION OF THIS DOCUMENT IS UMLIMIED h

Prepared for:

United States Department of Energy

Office of Science and Technology

Contract No. DE-AC02-76CH00016 


\section{TABLE OF CONTENTS}

Page

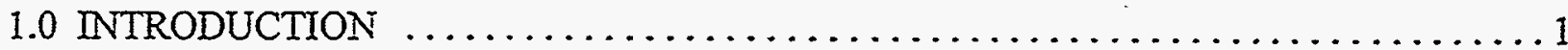

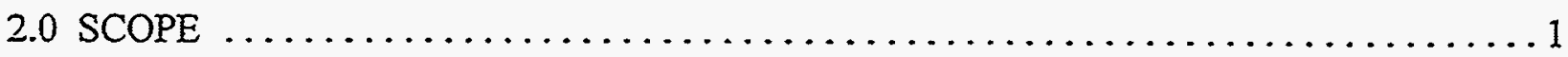



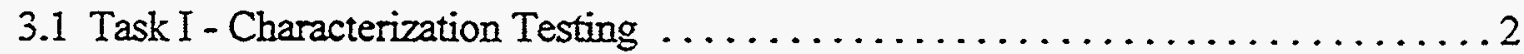

3.1.I Initial Characterization of INEEL Soil and Addition of $\mathrm{Hg} . \ldots \ldots \ldots \ldots 2$



3.1.3 TCLP of Spiked Soil and Soil with Additives . . . . . . . . . . 5

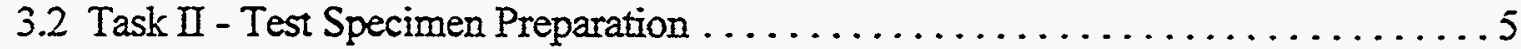

3.3 Task III - Performance Testing . . . . . . . . . . . . . . . . . . . . 10

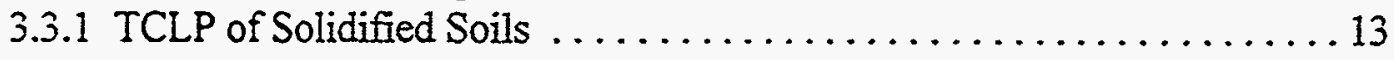

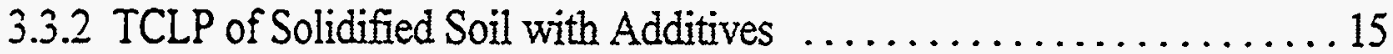

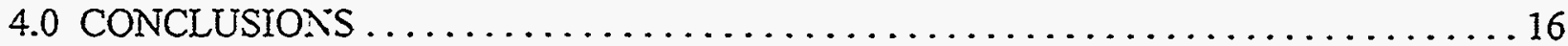

\section{LIST OF TABLES}

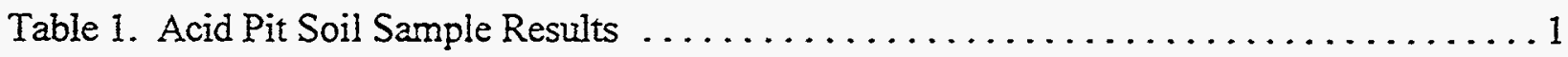

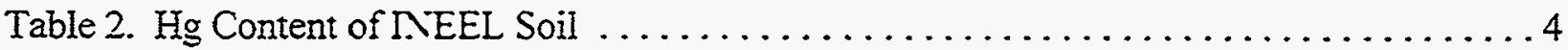

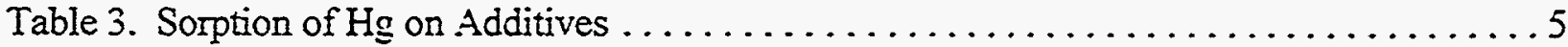

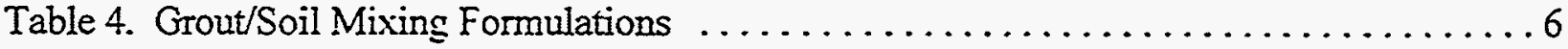

Table 5. Grout Compositions Densities ............................ 7

Table 6. Soil-Grout Composite Densities ............................. 7

Table 7. Test Specimen Sets and Associated Testing Requirements $\ldots \ldots \ldots \ldots \ldots \ldots$

Table 8. Compressive Strengths of Grouted Soils ......................... 11

Table 9. Hg Concentration in TCLP Leachate from Solidified Soil . . . . . . . . . . . 15

Table 10. Concentrations of $\mathrm{Hg}$ from TCLP of Solidified Soil Plus Additives ........... 16

\section{LIST OF FIGURES}

Figure 1. Varian, Liberty 100, Inductively Coupled Plasma Optical Emission Spectrometer. . . 3 Figure 2. High-Shear Laboratory Mixer Used for the Tect-Grout and Waxfix Samples. . . . . .8

Figure 3. Stabilized Soil Samples from the INEEL Acid Pit Treatability Study . . . . . . . . 9

Figure 4. Versa Tester Universal Compression Testing Instrument ................ 10

Figure 5. Perkin-Elmer Model 4000 Atomic Adsorption Spectrophotometer with the cold vapor generator for $\mathrm{Hg}$ analysis. . . . . . . . . . . . . . . . . . . . . . . 14 


\section{DISCLAIMIER}

Portions of this document may be illegible in electronic image products. Images are produced from the best available original dosemenent. 
This report was prepared as an account of work sponsored by an agency of the United States Government. Neither the United States Government nor any agency thereof, nor any of their employees, makes any warranty, express or implied, or assumes any legal liability or responsibility for the accuracy, completeness, or usefulness of any information, apparatus, product, or process disclosed, or represents that its use would not infringe privately owned rights. Reference herein to any specific commercial product, process, or service by trade name, trademark, manufacturer, or otherwise does not necessarily constitute or imply its endorsement, recommendation, or favoring by the United States Government or any agency thereof. The views and opinions of authors expressed herein do not necessarily state or reflect those of the United States Government or any agency thereof. 


\subsection{INTRODUCTION}

This report describes the contaminant-specific materials testing phase of the In Situ Stabilization Comprehensive Environmental Response, Compensation, and Liability Act (CERCLA) Treatability Study (TS). The purpose of materials testing is to measure the effectiveness of grouting agents to stabilize Idaho National Engineering and Environmental Laboratory (INEEL) Acid Pit soils and select a grout material for use in the Cold Test Demonstration and Acid Pit Stabilization Treatability Study within the Subsurface Disposal Area (SDA) at the Radioactive Waste Management Complex (RWMC). Test results will assist with selecting a grout material for the follow-on demonstrations described in Test Plan for the Cold Test Demonstration and Acid Pit Stabilization Phases of the In Situ Stabilization Treatability Study at the Radioactive Waste Management Complex (Galloway et. al. 1997).

\subsection{SCOPE}

The investigation-derived soil samples generated by the characterization study were classified as Resource Conservation and Recovery Act (RCRA) waste and were stored in drums at the INEEL MWSF, a RCRA treatment storage and disposal facility operated by the Waste Reduction Operations Complex (WROC). These soil samples were to be used for the laboratory mixing studies discussed in the project scope of work. The soil material selected for testing originated from Coreholes 11 and 12 from the 1991 Phase I borehole sampling for the Acid Pit Track 2 Characterization. Phase 1 sample analysis results indicated coreholes 11 and 12 had relatively high concentrations of mercury [ $>1000$ parts per million (ppm)]. Table 1 lists Phase I analytical results from the soil samples selected for sample retrieval.

Table 1. Acid Pit Soil Sample Results

\begin{tabular}{|c|c|c|c|c|c|c|}
\hline $\begin{array}{l}\text { Hole } \\
\text { No. }\end{array}$ & Depth & $\underset{(\mathbf{m g} / \mathbf{k g})}{\mathbf{H g}}$ & $\begin{array}{l}\text { Metals } \\
(\mathrm{mg} / \mathrm{kg})\end{array}$ & $\begin{array}{l}\text { Radionuclides } \\
\qquad(\mathrm{pCi} / \mathrm{g})\end{array}$ & $\begin{array}{l}\text { Organics } \\
\text { (ug/kg) }\end{array}$ & $\begin{array}{c}\text { Nonmetal } \\
\text { Inorganics } \\
(\mathrm{mg} / \mathrm{kg})\end{array}$ \\
\hline 11 & $14-16$ & 1420 & None reported & $\begin{array}{c}\text { Gamma emitting } \\
\text { Co-60 } 1.56 \\
\text { Cs-137 } 1.14 \\
\text { Eu-152 } 0.523 \\
\text { Alpha emitting } \\
\text { Pu-239 } 0.20 \\
\text { U-234 } 2.9 \\
\text { U-238 } 0.11 \\
\text { U-235 } 3.0\end{array}$ & $\begin{array}{c}\text { Volatile } \\
\text { Carbon tetrachloride } 24 \\
\text { Chloroform } 18 \\
\text { Trichloroethane } 18 \\
\text { Methylene chloride } 170 \\
\text { Acetone } 103 \\
\text { Semivolatile } \\
\text { Bis(2-ethylhexyl)phthalate } 5200 \\
\text { Tributylphosphate } 45,000\end{array}$ & $\begin{array}{l}\text { Nitrate } 5590 \\
\text { Sulfate } 10,600 \\
\text { TOC } 11,400\end{array}$ \\
\hline 12 & $14-16.8$ & 1030 & $\begin{array}{c}\text { Beryllium } 2.5 \\
\text { Alaminum } 27,800 \\
\text { Sodium } 658\end{array}$ & $\begin{array}{l}\text { Gamma emitting } \\
\text { None detected } \\
\text { Alpha emitting } \\
\text { U-234 } 3.0 \\
\text { U-238 } 2.5\end{array}$ & $\begin{array}{c}\text { Volatile } \\
\text { Methylene chloride } 160 \\
\text { Semivolatile } \\
\text { Bis(2-ethyihexyl)phthalate } 1040 \\
\text { Triburyiphosphate } 1100\end{array}$ & $\begin{array}{l}\text { Nitrate } 7890 \\
\text { TOC } 14,800 \\
\text { Magnesium } 9073 \\
\text { Sodium } 658\end{array}$ \\
\hline
\end{tabular}


The specific Acid Pit soil samples were retrieved and shipped to BNL for bench-scale materials testing. Because the Acid Pit soil samples were stored as RCRA waste, the BNL bench-scale grout studies were conducted as a RCRA TS. The primary objectives of the materials testing RCRA TS was to conduct mixing studies with actual Acid Pit soils and candidate grout materials to select a suitable grout for the Cold Test and Acid Pit Stabilization Demonstrations.

Parameters to be evaluated included contaminant stabilization, compressive strength, and implementability.

\subsection{DESCRIPTION OF LABORATORY STUDIES}

The technical support provided by BNL for the materials testing RCRA TS was divided into the following tasks:

Task I: Characterization Testing

Task II: Test Specimen Preparation

Task III: Performance Testing.

A 45-day RCRA treatability study notification was filed with the State of New York for performing the soil/grout tests at BNL. Samples were shipped to BNL before the 45-day approval to initiate characterization testing. Specimen preparation and performance testing did not commence until the 45-day notification had been approved.

\subsection{Task I - Characterization Testing}

The objective of Task I was to characterize the Acid Pit soils prior to performance testing. Before characterization testing, the soil was sized ( $3 / 8^{\prime \prime}$ sieve) and screened to produce a homogenous sample. A representative sample was collected from the composite mixture for characterization testing, including analytical testing to determine the total mercury concentration and soluble mercury concentration.

Five binding additives that could potentially enhance stabilization of the soluble mercury contamination are sodium sulfide, diatomaceous earth, zeolite, hematite, and fly ash.

\subsubsection{Initial Characterization of INEEL Soil and Addition of $\mathrm{Hg}$}

On receipt of the soil from INEEL, $5 \mathrm{~g}$ aliquots of soil were taken for: pre-TCLP testing of $\mathrm{pH}$. The samples were obtained from cans labeled: $\mathrm{CH} 11$ 10-12' and CH 11 14-16'. Results indicated that TCLP Leachant $\# 1$ should be used. Three sample were tested using the TCLP:

1. $\mathrm{CH} 11$ 10-12

2. $\mathrm{CH} 1114-16^{1}$

3. $\mathrm{CH} 1214-16^{\mathrm{r}}$ 
The TCLP leachate was filtered through type GF/F glass Whatman filters. Analysis of the leachate for $\mathrm{Hg}$ was done by ICP using EPA Method 200.7 Rev. 4.4 (1994) "Methods for the Determination of Metals in Environmental Samples, Supplement I. Determination of Metals and Trace Elements in Water and Wastes by ICP-AES". Analysis was conducted at $194.163 \mathrm{~nm}$ on a Varian, Liberty 100 ICP (Figure 1). Standards, an analytical blank, a reagent blank, and a reagent spike were prepared. The detection limit was estimated to be $0.1 \mathrm{ppm}$. No Hg was observed in any of the TCLP leachates. This was in contradiction with information from INEEL that the soil contained approximately $1000 \mathrm{ppm} \mathrm{Hg}$, which should give leachate concentrations of $50 \mathrm{ppm}$.

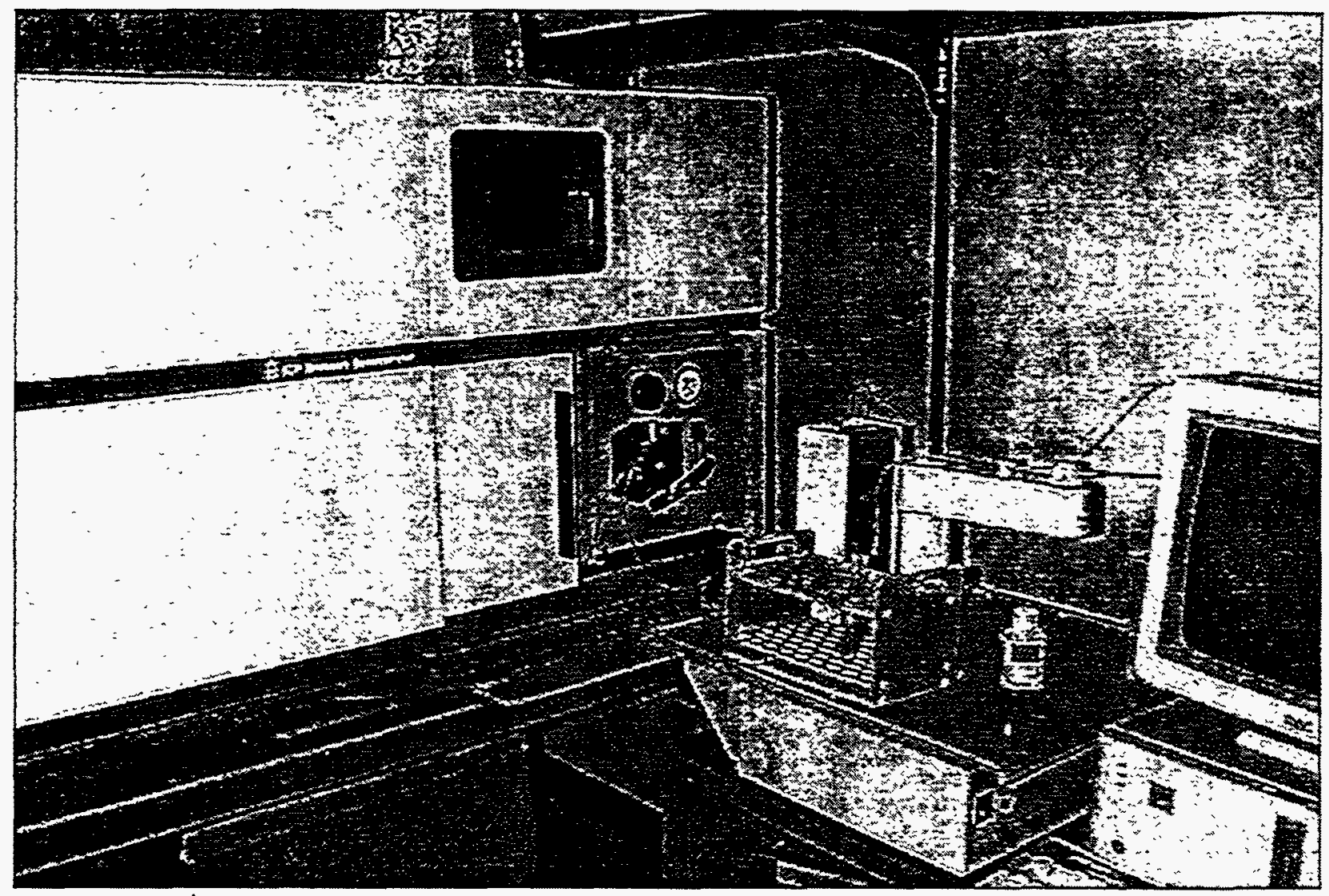

Figure 1. Varian, Liberty 100, Inductively Coupled Plasma Optical Emission Spectrometer.

To double check these results, digestions of samples of the INEEL soil were conducted according to $\mathrm{SW} 846$. Aliquots of the soil, weighing about $2 \mathrm{~g}$ were digested in $15 \mathrm{~mL}$ of concentrated $\mathrm{HCL}$ and $5 \mathrm{~mL}$ of concentrated $\mathrm{HNO}_{3}$. After reacting overnight the extract was filtered through Whatman \# 41 filter paper and brought up to $50 \mathrm{~mL}$ with distilled/deionized water. Results are shown in Table 2. 
Table 2. Hg Content of INEEL Soil

\begin{tabular}{|c|c|c|c|}
\hline Sample & Hg in Digest (ppm) & Dilution Factor & Hg in Soil (ppm) \\
\hline CH11 10-12' & $<0.1$ & 25.77 & $<2.6$ \\
\hline CH12 14-16' & 0.41 & 25.51 & 10.5 \\
\hline CH 11 14-16 & 0.47 & 21.01 & 9.9 \\
\hline
\end{tabular}

Based on these results it was decided to spike the soil with $\mathrm{Hg}$ to obtain a concentration similar to that known to exist in other samples of the INEEL soil. To do this, all of the soil remaining in the can containing CH11 14-16 was weighed into a 5 gallon plastic pail. The soil weighed 3244 g. A solution, containing $4.38 \mathrm{~g}$ of $\mathrm{HgCl}_{2}$ in one liter of distilled water, was mixed with the soil. This gave a very wet mixture which assured homogeneous mixing of the $\mathrm{Hg}$. The material was left to air dry in a hood.

Later it was determined that more spiked soil would be required. An additional $653.8 \mathrm{~g}$ of soil from $\mathrm{CH} 11$ 10-12' was added to the previously spiked soil, giving a total as received weight (of the spiked soil) of $3898 \mathrm{~g}$. A solution consisting of $0.88 \mathrm{~g}^{\circ} \mathrm{HgCl}_{2}$ in $200 \mathrm{~mL}$ of water was also added. After air drying for several days, with frequent mixing, the soil weight was $3448 \mathrm{~g}$. The soil was restored to its original water content by adding distilled water.

To check if the Hg concentration of the soil was acceptable, three small samples of the spiked soil were digested as described above. Concentrations of $\mathrm{Hg}$ in the three samples of spiked soil were: 878,1004 and $898 \mathrm{ppm}$, with an average of $927 \mathrm{ppm}$. This value, slightly lower than expected, may represent some loss of $\mathrm{Hg}$ to the vapor phase.

\subsubsection{Additives}

To minimize leaching of $\mathrm{Hg}$ from the solidified soil, it may be necessary to use an additive that is mixed in with the solidification agent. To determine the best additive to use, two series of tests were run in which the sorption of $\mathrm{Hg}$ by each of the additives was assessed. In one series, $1 \mathrm{~g}$ of each additive was weighed out and added to a bottle containing $40 \mathrm{~g}$ of a solution containing $\mathrm{Hg}$. The $\mathrm{pH}$ of the solution had been adjusted to 7.8. In the second series, $0.5 \mathrm{~g}$ of additive was added to $9 \mathrm{~g}$ of solution. Results are shown in Table 3 . Based on concentrations of $\mathrm{Hg}$ in the liquid after the tests, three materials outperformed the others: sodium sulfide, hematite and iron powder. 
Table 3. Sorption of Hg on Additives

\begin{tabular}{|c|c|c|c|c|c|c|}
\hline Additive & Source & $\begin{array}{l}W t \\
(g)\end{array}$ & $\begin{array}{l}\text { Vol } \\
\text { (mL) }\end{array}$ & $\begin{array}{c}\text { Hg Start } \\
(\mu \mathrm{g} / \mathrm{g})\end{array}$ & $\begin{array}{c}\text { Hg End } \\
(\mu \mathrm{g} / \mathrm{g})\end{array}$ & $\begin{array}{c}\text { Mass of } \mathbf{H g} \\
\text { Sorbed } \\
(\mu \mathrm{g} / \mathrm{g})\end{array}$ \\
\hline Clinoptilolite & Teaque Minerals & 1 & 40 & 52 & 51.6 & 16 \\
\hline Fly Ash, Type F & Detroit Edison & 1 & 40 & 52 & 33.4 & 744 \\
\hline $\mathrm{Na}_{2} \mathrm{~S} .9 \mathrm{H}_{2} \mathrm{O}$ & reagent & 1 & 40 & 52 & 0.72 & 2050 \\
\hline hematite & P. Shaw & 1 & 40 & 52 & 1.98 & 2000 \\
\hline $\begin{array}{l}\text { diatomaceous } \\
\text { earth }\end{array}$ & $\begin{array}{l}\text { Vortex Diatom } \\
\text { Filter Powder }\end{array}$ & 1 & 40 & 52 & 41.1 & 440 \\
\hline $\mathrm{Fe}_{2} \mathrm{O}_{3}$ (red) & Fisher & 0.5 & 9 & 34 & 13.4 & 370 \\
\hline $\begin{array}{c}\text { Iron powder } \\
\mathrm{Fe}^{0}\end{array}$ & $\begin{array}{l}\text { electrolytic } \\
\text { reagent }\end{array}$ & 0.5 & 9 & 34 & 0.6 & 600 \\
\hline limonite & Ward's & 0.5 & 9 & 34 & 3.2 & 554 \\
\hline $\mathrm{Fe}_{3} \mathrm{O}_{4}$ (black) & Alfa Products & 0.5 & 9 & 34 & 4.4 & 533 \\
\hline
\end{tabular}

\subsubsection{TCLP of Spiked Soil and Soil with Additives}

To minimize leachability of $\mathrm{Hg}$, several grout formulations were prepared with additives that were determined to inhibit the release of $\mathrm{Hg}$ to the TCLP solution. Preliminary to this, a set of TCLP tests were conducted in which the behavior of the additives in the presence of spiked soil was assessed. Three samples were prepared. One was the spiked soil for use as a reference, the second was the spiked soil with $1 \%$ (by weight) of $\mathrm{Fe}^{0}$, and the third was spiked soil with $1 \%$ of $\mathrm{Na}_{2} \mathrm{~S} .9 \mathrm{H}_{2} \mathrm{O}$. The tests were run according to the TCLP protocol except that the mass and volume of the sample was reduced to conserve the spiked soil. The ratio of solid to liquid was kept the same in all cases so results are directly comparable. The concentration of $\mathrm{Hg}$ in the leachate from the spiked soil was $23.9 \mathrm{ppm}$. This is far in excess of the TCLP limit of $0.2 \mathrm{ppm}$ and amounts to about half of the total $\mathrm{Hg}$ in the soil. Results were similar for the soil with the iron powder, with $\mathrm{Hg}$ concentrations of $22.4 \mathrm{ppm}$ in the leachate. The concentration of $\mathrm{Hg}$ in leachate from the soil with $\mathrm{Na}_{2} \mathrm{~S} .9 \mathrm{H}_{2} \mathrm{O}$ was below the detection limit of $0.1 \mathrm{ppm}$.

\subsection{Task II - Test Specimen Preparation}

Five grouting materials were tested including two commercially available materials and three innovative materials. The two commercial grouts are Type I and Type $\mathrm{H}$ (similar to Type V) Portland cement. The three innovative grouting systems tested are Tect I, paraffin wax 
(WaxFix), and a special magnesium phosphate cement. The innovative materials were • formulated and provided by two different vendors. Tect I and WaxFix were provided by Carter Technologies (Contact-Ernie Carter). The third innovative grout tested, magnesium phosphate, was supplied by D. Singh from Argonne National Laboratory (ANL)-Chicago.

Test specimens were prepared/mixed using the standard grout/contaminated soil formulations listed in Table 4.

Table 4. Grout/Soil Mixing Formulations

\begin{tabular}{|l|c|c|}
\hline Grout Type & Grout & Soil \\
\hline TECT I & $110 \mathrm{~mL}$ & $100 \mathrm{gm}$ \\
\hline Paraffin & $45 \mathrm{~mL}$ & $100 \mathrm{gm}$ \\
\hline Type H Portland & $90 \mathrm{~mL}$ & $100 \mathrm{gm}$ \\
\hline Type I Portland & $90 \mathrm{~mL}$ & $100 \mathrm{gm}$ \\
\hline Phosphate Cement & $50 \mathrm{~mL}$ & $100 \mathrm{gm}$ \\
\hline
\end{tabular}

Prior to sample preparation a series of measurements were made to determine the density of each grout. This information was required in order to prepare the proper volume of grout. The manufacturers mixing directions for the innovative grouts and the INEEL supplied cement grout formulations were given by weight of components (i.e. I mass part Portland cement to 1 mass part water). Grout compositions and densities as used are given in Table 5. The Tect I grout was mixed in a high shear mixer. The portland cements and Waxfix were mixed by hand. The MagPhosphate cement samples were prepared by Deleep Singh during a visit to BNL. 
Table 5. Grout Compositions/Densities

\begin{tabular}{|l|l|l|l|l|}
\hline \multicolumn{1}{|c|}{ Grout Type } & \multicolumn{1}{|c|}{ Wt of Solid } & Wt of Liquid & $\begin{array}{c}\text { Volume } \\
\text { Produced }\end{array}$ & $\begin{array}{c}\text { Density of } \\
\text { Grout }\end{array}$ \\
\hline Tect I/Tect-Hg & 200 g powder & $72.4 \mathrm{~g}$ liquid & $120 \mathrm{ml}$ & $2.27 \mathrm{~g} / \mathrm{cm}^{3}$ \\
\hline Portland Type I & 50 g powder & $50 \mathrm{~g}$ water & $67 \mathrm{ml}$ & $1.49 \mathrm{~g} / \mathrm{cm}^{3}$ \\
\hline Portland Type H & 50 g powder & $50 \mathrm{~g}$ water & $67 \mathrm{ml}$ & $1.49 \mathrm{~g} / \mathrm{cm}^{3}$ \\
\hline Waxfix & $100 \mathrm{~g}$ Waxfix 125 & $12 \mathrm{~g}$ Waxfix 12 & $57 \mathrm{ml}$ & $0.88 \mathrm{~g} / \mathrm{cm}^{3}$ \\
\hline
\end{tabular}

After grout densities were measured, it was necessary to determine final sample densities to determine how large each lot should be. From the formulation in table one, $100 \mathrm{~g}$ of INEEL soil were mixed with the requisite amount of grout and poured into a graduated mold. Soil/grout densities are given in Table 6.

Table 6. Soil-Grout Composite Densities

\begin{tabular}{|l|c|}
\hline Grout Type & Soil/Grout Product Density \\
\hline Tect I/Tect-Hg & $2.12 \mathrm{~g} / \mathrm{cm}^{3}$ \\
\hline Portland Type I & $1.75 \mathrm{~g} / \mathrm{cm}^{3}$ \\
\hline Portland Type H & $1.75 \mathrm{~g} / \mathrm{cm}^{3}$ \\
\hline Waxfix & $1.40 \mathrm{~g} / \mathrm{cm}^{3}$ \\
\hline
\end{tabular}

Each lot was formulated to produce $350 \mathrm{ml}$ of product. Each grout lot was introduced into a cylindrical polyvinyl chloride (PVC) pipe mold measuring approximately $26-35 \mathrm{~cm}$ in length and $3.8 \mathrm{~cm}$ in diameter. The soil used was the mercury spiked soil prepared earlier. From the grout densities, component quantities were calculated to make 3 samples, each having a volume of $90 \mathrm{~mL}$, in each mold. Additional material was used in each mold to allow for $10 \%$ loss for cutting samples. To assure that the samples were homogeneous, the samples were cut from the center of the mold, leaving about $4 \mathrm{~cm}$ on each end of the solidified material in the mold as waste after cutting.

Tect I and Tect-Hg samples were mixed in a high shear laboratory mixer (Figure 2). The product was very thick and had to be vibrated into the molds. After pouring and vibrating for one to two minutes the mold was capped and allowed to cure for thirty days. Waxfix samples were made by melting the wax at $75^{\circ} \mathrm{C}$ and mixing in the Waxfix 12 using the high shear mixer. The still molten wax mix was added to the soil and mixed by hand. Due to cooling by the soil the mix 
hardened to a point that it had to be reheated. [Note: We did not preheat the soil for fear of driving off some of the mercury. Once wetted with the wax, the mercury would be less likely to escape.] After reheating, the wax-soil blend was re-mixed and poured with light vibration, into the mold. The mold was capped and left for thirty days. The portland cement samples [Type I and Type $\mathrm{H}$ ) were mixed by hand. The grout was added to the soil and stirred until no clumping was observed. The mix was poured into the PVC mold, capped and allowed to cure for thirty days. The Mag-Phosphate cement samples were prepared by Deleep Singh during a visit to BNL. They were hand mixed and poured into similar PVC mold and allowed to cure.

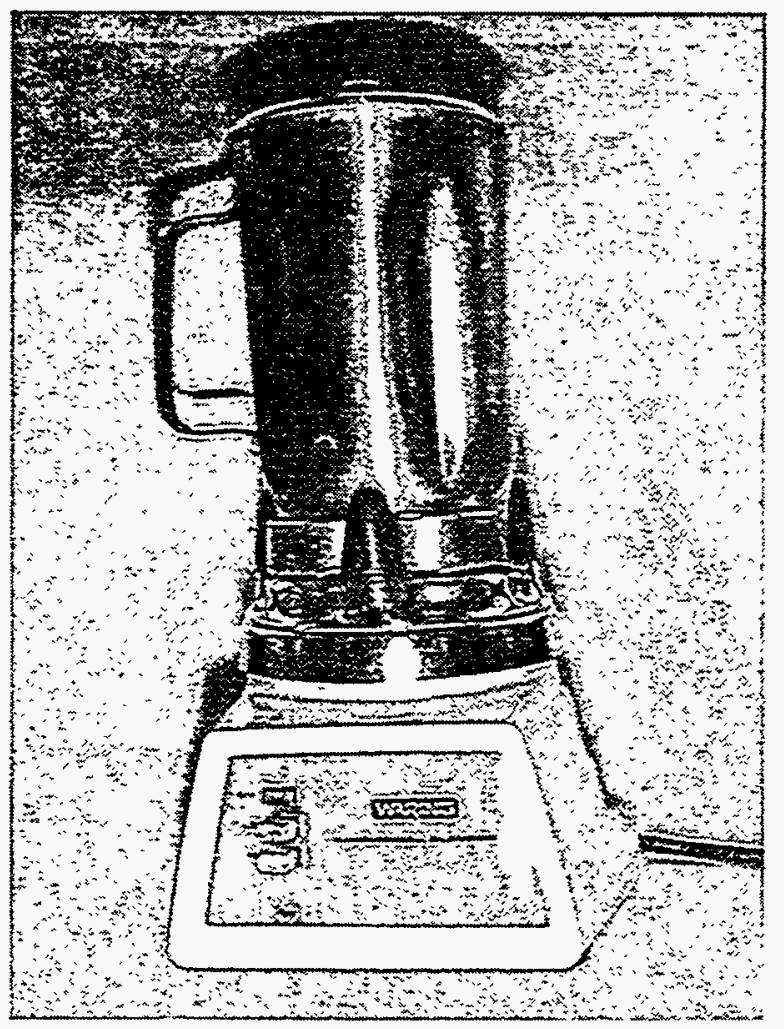

Figure 2. High-shear laboratory mixer used for the Tect-grout and Waxfix samples.

At the end of thirty days the caps were removed from all the molds and the molds and samples were cut into $7.6-\mathrm{cm}$ lengths using a wet masonry-saw with a diamond-impregnated blade. The PVC casing was then removed from each individual sample. The samples were measured, weighed and numbered and then stored in 100\% relative humidity until compressive strength measurements were made. Figures 3 depicts, from left to right, typical samples of Waxfix, Tect I, Mag-Phosphate cement, Tect-Hg and Portland Type I cement samples after curing, cutting and demolding. 


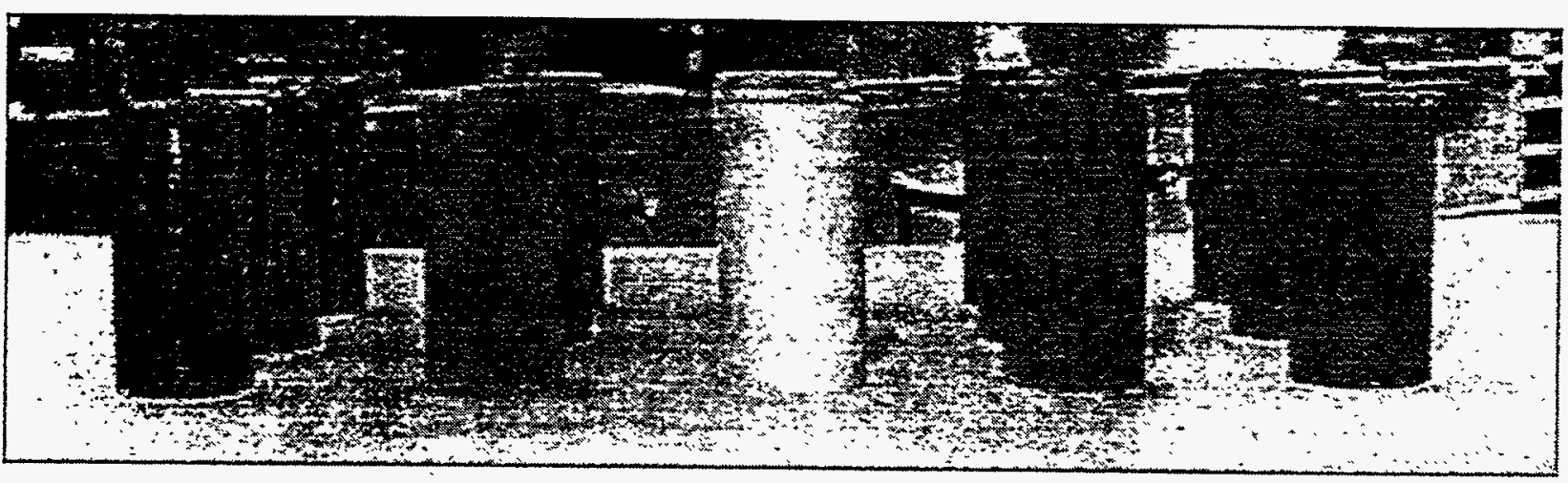

Figure 3. Stabilized Soil Samples from the INEEL Acid Pit Treatability Study.

The same procedures were repeated for the grouts with the sodium sulfide additive. The mass of sulfide added was $2 \%$ of the soil mass. For the cements and TECT products the sulfide was dissolved into the liquid part. For the Waxfix, the sulfide was pulverized into a fine powder and thoroughly mixed into the molten wax grout. Table 7 lists the number of test specimen sets that were prepared for each grout material and the tests performed on each set. Appendix A gives the measurements weights and densities of the samples tested.

Table 7. Test Specimen Sets and Associated Testing Requirements

\begin{tabular}{|l|c|c|c|}
\hline Grout Type & Mixture Specification & $\begin{array}{c}\text { Total Compressive } \\
\text { Strength Samples }\end{array}$ & $\begin{array}{c}\text { Total TCLP } \\
\text { Samples* }\end{array}$ \\
\hline $\begin{array}{l}\text { Magnesium } \\
\text { Phosphate Cement }\end{array}$ & No binding agent & 3 & 2 \\
\hline \multirow{3}{*}{ TECT } & No binding agent & 3 & 2 \\
\cline { 2 - 4 } & Sodium Sulfide additive & 3 & 2 \\
\cline { 2 - 4 } & Special mixture (Tect-Hg) & 3 & 2 \\
\hline \multirow{3}{*}{ Paraffin } & No binding agent & 3 & 2 \\
\cline { 2 - 4 } & Sodium Sulfide additive & 3 & 2 \\
\hline \multirow{2}{*}{ Type H Portland } & No binding agent & 3 & 2 \\
\cline { 2 - 5 } & Sodium Sulfide additive & 3 & 2 \\
\hline \multirow{2}{*}{ Type I Portiand } & No binding agent & 3 & 2 \\
\cline { 2 - 5 } & Sodium Sulfide additive & 3 & 2 \\
\hline
\end{tabular}

*Compressive strength samples were used for TCLP analyses of mercury. 


\subsection{Task III - Performance Testing}

The objective of Task III was to evaluate the grout properties through a series of two standard tests; compressive strength and TCLP. The tests provided information for selecting a grout material for field demonstration testing.

Baseline compressive strength measurements were performed on test specimens of Acid Pit soils mixed with Tect I, Tect-Hg, Type I and Type H Portland cement, Magnesium-Phosphate cement, Tect I with additive, and Portland Type I and Type $H$ with additive following American Society for Testing and Materials (ASTM) C-39, "Standard Test Method for Compressive Strength of Cylindrical Concrete Specimens." The Waxfix and Waxfix with additive sample sets were compression tested using ASTM D-695, "Standard Test Method for Compressive Properties of Rigid Plastic." The grout/soil mixtures were compression tested in triplicate on a Versa Tester Universal Compression Testing Instrument (Figure 4). At the failure point the samples fractured and pieces flew off. Plastic bags, placed around the samples and taped shut were used to capture all the fragments of the samples during the compressive loading. This served two purposes; to collect all the mixed waste particulates for health and safety and to collect the fragments to use later on in the TCLP analysis.

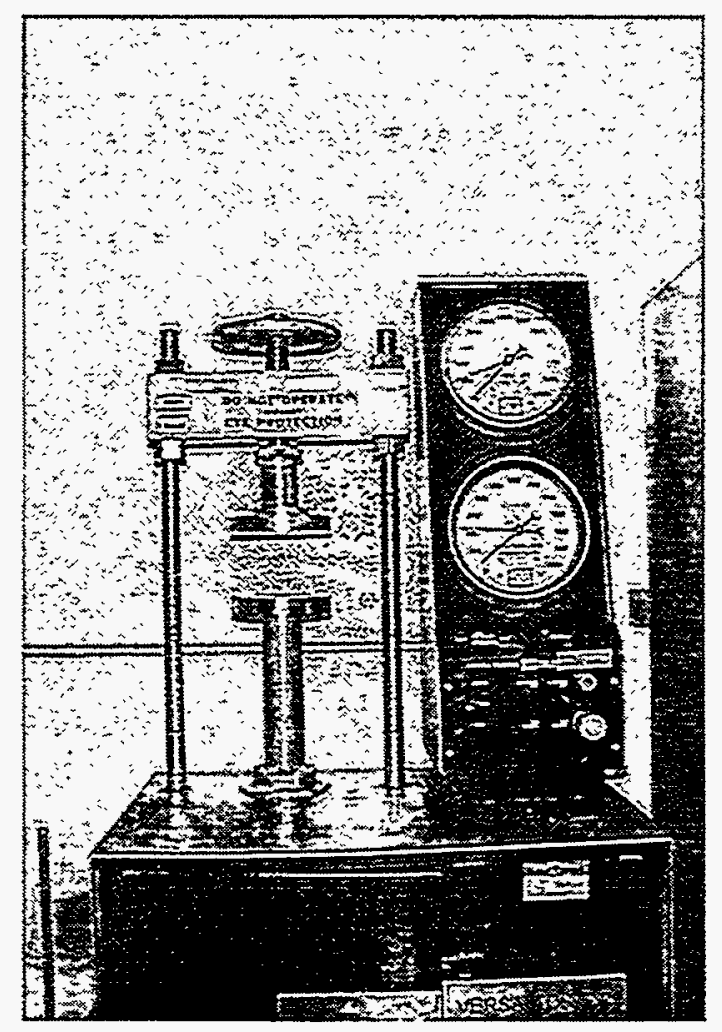

Figure 4. Versa Tester Universal Compression Testing Instrument 
Results of the compressive strength testing are given in Table 8.

Table 8. Compressive Strengths of Grouted Soils

\begin{tabular}{|c|c|c|c|c|}
\hline Grout Type & ID & $\begin{array}{l}\text { Load, } \\
\text { Lbs }\end{array}$ & $\begin{array}{l}\text { Compressive } \\
\text { Strength, psi }\end{array}$ & $\begin{array}{c}\text { Compressive } \\
\text { Strength, MPa }\end{array}$ \\
\hline \multirow[t]{5}{*}{ Waxfix } & $1-1$ & 260 & 130 & 0.9 \\
\hline & $1-2$ & 290 & 150 & 1.0 \\
\hline & $1-\hat{3}$ & 300 & 150 & 1.1 \\
\hline & Avg & 280 & 140 & 1.0 \\
\hline & Std. dev. & 17 & 9 & 0.1 \\
\hline \multirow[t]{5}{*}{ Tect-Hg } & $2-1$ & 2280 & 1120 & 7.7 \\
\hline & $2-2$ & 4360 & 2140 & 14.8 \\
\hline & $2-\hat{z}$ & 4820 & 2370 & 16.3 \\
\hline & Avg & 3820 & 1880 & 12.9 \\
\hline & Std. dev. & 1100 & 543 & 3.7 \\
\hline \multirow{5}{*}{$\begin{array}{l}\text { Portland Type I } \\
\text { Cement }\end{array}$} & $3-1$ & 3070 & 1510 & 10.4 \\
\hline & $3-2$ & 3340 & 1640 & 11.3 \\
\hline & $\hat{\jmath}-\hat{\jmath}$ & 3380 & 1660 & 11.4 \\
\hline & Avg & 3260 & 1600 & 11.1 \\
\hline & Std. dev. & 138 & 68 & 0.5 \\
\hline \multirow[t]{5}{*}{ Tect I } & $4-1$ & 4880 & 2400 & 16.5 \\
\hline & $4-2$ & 3740 & 1840 & 12.7 \\
\hline & $4-3$ & 4860 & 2390 & 16.5 \\
\hline & Avg & 4490 & 2210 & 15.2 \\
\hline & Std. dev. & 533 & 262 & 1.8 \\
\hline \multirow{5}{*}{$\begin{array}{l}\text { Mag-Phosphate } \\
\text { Cement }\end{array}$} & $5-1$ & 280 & 140 & 0.9 \\
\hline & $5-2$ & 310 & 150 & 1.0 \\
\hline & $5-3$ & 300 & 150 & 1.0 \\
\hline & Avg & 300 & 140 & 1.0 \\
\hline & Std. dev. & 12 & 7 & 0.0 \\
\hline
\end{tabular}


Table 8. Compressive Strengths of Grouted Soils (continued)

\begin{tabular}{|c|c|c|c|c|}
\hline Grout Type & $m$ & $\begin{array}{l}\text { Load, } \\
\text { Lbs }\end{array}$ & $\begin{array}{l}\text { Compressive } \\
\text { Strength, psi }\end{array}$ & $\begin{array}{l}\text { Compressive } \\
\text { Strength, MPPa }\end{array}$ \\
\hline \multirow{5}{*}{$\begin{array}{l}\text { Waxfix with Sodium } \\
\text { Sulfide }\end{array}$} & $6-1$ & 240 & 120 & 0.8 \\
\hline & $6-2$ & 320 & 160 & 1.1 \\
\hline & $6-3$ & 300 & 150 & 1.0 \\
\hline & Avg & 290 & 140 & 1.0 \\
\hline & Std. dev. & 34 & 17 & 0.1 \\
\hline \multirow{5}{*}{$\begin{array}{l}\text { Tect I with Sodium } \\
\text { Sulfide }\end{array}$} & $7-1$ & 4960 & 2440 & 16.8 \\
\hline & $7-2$ & 3180 & 1560 & 10.8 \\
\hline & $7-3$ & 3520 & 1710 & 11.8 \\
\hline & Avg & 3890 & 1900 & 13.1 \\
\hline & Std. dev. & 772 & 382 & 2.6 \\
\hline \multirow{5}{*}{$\begin{array}{l}\text { Portland Type I with } \\
\text { Sodium Sulfide }\end{array}$} & $8-1$ & 2320 & 1140 & 7.9 \\
\hline & $8-2$ & 1960 & 960 & 6.6 \\
\hline & $8-3$ & 2120 & 1040 & 7.2 \\
\hline & Avg & 2130 & 1050 & 7.2 \\
\hline & Std. dev. & 147 & 72 & 0.5 \\
\hline \multirow{5}{*}{$\begin{array}{l}\text { Portland Type H } \\
\text { with Sodium Sulfide }\end{array}$} & $9-1$ & 1200 & 580 & 4.0 \\
\hline & $9-2$ & 1400 & 680 & 4.7 \\
\hline & $9-3$ & 1360 & 670 & 4.6 \\
\hline & Avg & 1320 & 640 & 4.4 \\
\hline & Std. dev. & 86 & 43 & 0.3 \\
\hline \multirow[t]{5}{*}{ Portland Type H } & $10-1$ & 1320 & 650 & 4.5 \\
\hline & $10-2$ & 1360 & 670 & 4.6 \\
\hline & $10-3$ & 1060 & 520 & 3.6 \\
\hline & Avg & 1250 & 610 & 4.2 \\
\hline & Std. dev. & 133 & 65 & 0.5 \\
\hline
\end{tabular}


After compressive strength testing, duplicate samples of each grout/soil mixture were subjected to TCLP analyses for mercury. The procedures used for TCLP analyses were EPA method SW846 1311 for TCLP Extraction and EPA method SW846 method 7470, "Mercury"(Hg in Liquid Wastes-Manual Cold Vapor Method).

Size reduction was required to ensure the waste was smaller than $1 \mathrm{~cm}$ in its narrowest dimension [i.e., capable of passing through a 9.5 -mm $(0.375$-in.) standard sieve]. Immediately following compressive strength testing, sample fragments were taken and further reduced in size. This was done by placing the fragments into multiple layers of plastic bags and striking the fragments with a hammer. The crushed pieces where then sieved using a series of sieves, starting with a $9.5 \mathrm{~mm}$ sieve, followed by an $8 \mathrm{~mm}$, to a $6.7 \mathrm{~mm}$, to a $4.75 \mathrm{~mm}$, to a $1 \mathrm{~mm}$ and finally a catch pan. The 100 grams of material required for TCLP testing was obtained primarily from the material passing through the $9.5 \mathrm{~mm}$ sieve but retained on the $8 \mathrm{~mm}$ sieve. If $100 \mathrm{~g}$ could not be collected from the $9.5 \mathrm{~mm}$ sizing then material that passed the $8 \mathrm{~mm}$ sieve but was retained by the $6.7 \mathrm{~mm}$ was used. If this still did not collect 100 grams, then material that passed the $6.7 \mathrm{~mm}$ but was retained by the $4.75 \mathrm{~mm}$ sieve was used. In no case was it necessary to go below the $4.75 \mathrm{~mm}$ sizing. Five grams of material that passed through the $1 \mathrm{~mm}$ sieve were used to determine which TCLP leachate would be utilized ( 1 or 2 , see TCLP characterization).

\subsubsection{TCLP of Solidified Soils}

A series of TCLP tests were conducted on soils that had been solidified with various reagents. A $5 \mathrm{~g}$ subsample of each was tested for $\mathrm{pH}$ as per the TCLP protocol. Four of the solidified product samples required type 1 leachant, while the portland cement material required type 2 leachant because of its high alkalinity.

While analysis of $\mathrm{Hg}$ for screening tests was done by ICP, analysis for other tests was performed by the Cold Vapor method required by the EPA. This method, \#7470, includes a digestion process which was also done. A Perkin Elmer model 4000 atomic absorption spectrophotometer, as shown in Figure 5, was used with an MHS-10 vapor generation system. Reagents were made fresh daily. Three standards and a reagent blank were processed with each batch of samples. A 50-fold dilution was made of each sample prior to digestion. Twenty $\mathrm{mL}$ of sample (including digestion reagents) were used in each cold vapor analysis. Results are given in Table 9. From these data, it is apparent that only the Tect-Hg grout unequivocally passed the TCLP limit for $\mathrm{Hg}$ of $200 \mathrm{ppb}$. The next best material was the Tect I grout. 


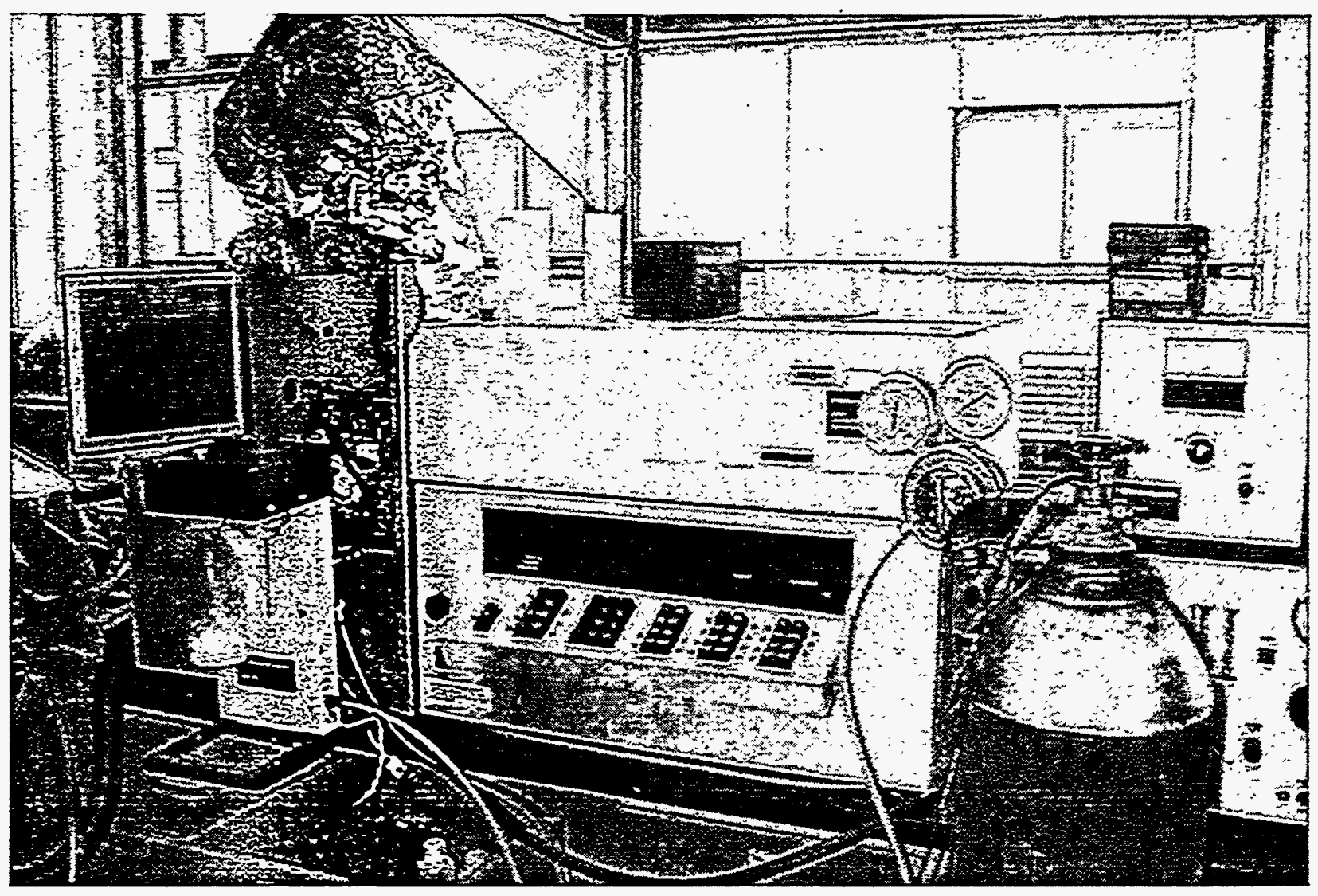

Figure 5. Perkin-Elmer Model 4000 Atomic Adsorption Spectrophotometer with the cold vapor generator for $\mathrm{Hg}$ analysis. 
Table 9. Hg Concentration in TCLP Leachate from Solidified Soil

\begin{tabular}{|c|c|c|}
\hline Sample & Material & Hg $(\mathbf{p p b})$ \\
\hline $1-1$ & WAXFIX & 630 \\
\hline $1-2$ & WAXFIX & 630 \\
\hline $2-1$ & Tect-Hg & 48 \\
\hline $2-2$ & Tect-Hg & 5.4 \\
\hline $3-1$ & portland type I cement & 570 \\
\hline $3-2$ & portland type I cement & 630 \\
\hline $4-1$ & Tect I (no additive) & 200 \\
\hline $4-2$ & Tect I (no additive) & 150 \\
\hline $5-1$ & Mag-phosphate & 530 \\
\hline $5-2$ & Mag-phosphate & 600 \\
\hline Reagent Blank & TCLP reagent & 0.3 \\
\hline
\end{tabular}

\subsubsection{TCLP of Solidified Soil with Additives}

In addition to the solidified soils, a set of 5 grout materials, 4 with additives, were prepared and tested with the TCLP protocol. Three materials were based on portland cement and required the type 2 leachant, while the other two required type I. In every case the additive was $\mathrm{Na}_{2} \mathrm{~S}$. Results are shown in Table 10 . Use of the additive profoundly reduced the concentration of $\mathrm{Hg}$ in the TCLP leachate, with all concentrations being significantly below the required $200 \mathrm{ppb}$. In fact, both types of portland cement containing the $\mathrm{Na}_{2} \mathrm{~S}$ additive had releases of $\mathrm{Hg}$ that were no greater than the reagent blank for the analysis, indicating that $\mathrm{Hg}$ releases were below detection. The Tect I grout had only slightly higher $\mathrm{Hg}$ concentrations in the leachate; the difference between this material and the portland cements, as far as TCLP leaching is concerned, is negligible. The Type $H$ portland cement (without additives), as with the other portland cements, did not pass the TCLP. 


\subsection{CONCLUSIONS}

Of the as-received materials tested, only the Tect-Hg passed the TCLP. When $\mathrm{Na}_{2} \mathrm{~S}$ was added, all materials passed TCLP.

Table 10. Concentrations of $\mathrm{Hg}$ from TCLP of Solidified Soil Plus Additives

\begin{tabular}{|c|c|c|}
\hline Sample & Material & $\mathbf{H g}(\mathbf{p p b})$ \\
\hline $6-1$ & Waxfix $\div \mathrm{Na}_{2} \mathrm{~S}$ & 11.6 \\
\hline $6-2$ & Waxfix $+\mathrm{Na}_{2} \mathrm{~S}$ & 14.6 \\
\hline $7-1$ & Tect $\mathrm{I} \div \mathrm{Na}_{2} \mathrm{~S}$ & 0.6 \\
\hline $7-2$ & Tect $\mathrm{I} \div \mathrm{Na}_{2} \mathrm{~S}$ & 0.7 \\
\hline $8-1$ & portland type $\mathrm{I} \div \mathrm{Na}_{2} \mathrm{~S}$ & 0.3 \\
\hline $8-2$ & portland type $\mathrm{I}+\mathrm{Na}_{2} \mathrm{~S}$ & 0.3 \\
\hline $9-1$ & portland type $\mathrm{H} \div \mathrm{Na}_{2} \mathrm{~S}$ & 0.5 \\
\hline $9-2$ & portland type $\mathrm{H} \div \mathrm{Na}_{2} \mathrm{~S}$ & 0.3 \\
\hline $10-1$ & portland type $\mathrm{H}$ & 428 \\
\hline $10-2$ & portland type $\mathrm{H}$ & 272 \\
\hline Reagent Blank & & 0.3 \\
\hline
\end{tabular}


Appendix A. Test Specimen Data

\begin{tabular}{|c|c|c|c|c|c|c|}
\hline Sample ID & $\begin{array}{l}\text { Diameter } \\
\mathrm{cm}\end{array}$ & $\begin{array}{l}\text { Length } \\
\mathrm{cm}\end{array}$ & $\begin{array}{l}\text { Weight } \\
\text { g }\end{array}$ & $\begin{array}{l}\text { Surface Area } \\
\mathrm{cm}^{2}\end{array}$ & $\begin{array}{l}\text { Volume } \\
\mathrm{cm}^{3}\end{array}$ & $\begin{array}{l}\text { Density } \\
\mathrm{g} / \mathrm{cm}^{3}\end{array}$ \\
\hline \multicolumn{7}{|l|}{ Waxfix } \\
\hline $1-1$ & 4.04 & 7.87 & 140.3 & 12.8 & 101 & 1.39 \\
\hline $1-2$ & 4.04 & 7.90 & 144.0 & 12.8 & 101 & 1.42 \\
\hline $1-3$ & 4.01 & 7.85 & 133.0 & 12.6 & 99 & 1.34 \\
\hline avg. & 4.03 & 7.87 & 139.1 & 12.8 & 100 & 1.38 \\
\hline std. dev. & 0.01 & 0.02 & 4.6 & 0.1 & 0.84 & 0.03 \\
\hline \multicolumn{7}{|l|}{ Tect-Hg } \\
\hline $2-1$ & 4.09 & 7.92 & 200.0 & 13.1 & 104 & 1.92 \\
\hline $2-2$ & 4.09 & 7.92 & 200.4 & 13.1 & 104 & 1.93 \\
\hline $2-3$ & 4.09 & 7.90 & 201.6 & 13.1 & 104 & 1.94 \\
\hline avg. & 4.09 & 7.92 & 200.7 & 13.1 & 104 & 1.93 \\
\hline std. dev. & 0.00 & 0.01 & 0.7 & 0.0 & 0.16 & 0.01 \\
\hline \multicolumn{7}{|c|}{ Portland Cement Type I } \\
\hline $3-1$ & 4.09 & 7.92 & 167.8 & 13.1 & 104 & 1.61 \\
\hline $3-2$ & 4.09 & 7.92 & 167.7 & 13.1 & 104 & 1.61 \\
\hline $3-3$ & 4.09 & 7.92 & 168.1 & 13.1 & 104 & 1.61 \\
\hline avg. & 4.09 & 7.92 & 167.9 & 13.1 & 104 & 1.61 \\
\hline std. dev. & 0.00 & 0.00 & 0.2 & 0.0 & 0.00 & 0.00 \\
\hline \multicolumn{7}{|c|}{ T'ect I w/no additive } \\
\hline $4-1$ & 4.09 & 7.90 & 206.0 & 13.1 & 104 & 1.99 \\
\hline $4-2$ & 4.09 & 7.92 & 204.0 & 13.1 & 104 & 1.96 \\
\hline $4-3$ & 4.09 & 7.92 & 203.7 & 13.1 & 104 & 1.96 \\
\hline avg. & 4.09 & 7.92 & 204.6 & 13.1 & 104 & 1.97 \\
\hline
\end{tabular}




\begin{tabular}{|c|c|c|c|c|c|c|}
\hline std. dev. & 0.00 & 0.01 & 1.0 & 0.0 & 0.16 & 0.01 \\
\hline \multicolumn{7}{|c|}{ Mag-Phosphate Cement } \\
\hline $5-1$ & 4.11 & 7.90 & 163.4 & 13.3 & 105 & 1.56 \\
\hline $5-2$ & 4.09 & 7.85 & 162.9 & 13.1 & 103 & 1.58 \\
\hline $5-3$ & 4.11 & 7.85 & 165.2 & 13.3 & 104 & 1.58 \\
\hline avg. & 4.11 & 7.87 & 163.8 & 13.2 & 104 & 1.57 \\
\hline std. dev. & 0.01 & 0.02 & 1.0 & 0.1 & 0.81 & 0.01 \\
\hline \multicolumn{7}{|c|}{ Waxfix w/Sodium Sulfide } \\
\hline $6-1$ & 4.09 & 7.82 & 142.2 & 13.1 & 103 & 1.38 \\
\hline $6-2$ & 4.09 & 7.82 & 146.7 & 13.1 & 103 & 1.43 \\
\hline $6-3$ & 4.09 & 7.85 & 137.8 & 13.1 & 103 & 1.34 \\
\hline avg. & 4.09 & 7.83 & 142.2 & 13.1 & 103 & 1.38 \\
\hline std. dev. & 0.00 & 0.01 & 3.6 & 0.0 & 0.16 & 0.04 \\
\hline \multicolumn{7}{|c|}{ Tecl I w/Sodium Sulfide } \\
\hline $7-1$ & 4.09 & 7.82 & 202.4 & 13.1 & 103 & 1.97 \\
\hline $7-2$ & 4.09 & 7.82 & 203.9 & 13.1 & 103 & 1.98 \\
\hline 7.3 & 4.11 & 7.80 & 206.3 & 13.3 & 104 & 1.99 \\
\hline avg. & 4.10 & 7.81 & 204.2 & 13.2 & 103 & 1.98 \\
\hline std. dev. & 0.01 & 0.01 & 1.6 & 0.1 & 0.44 & 0.01 \\
\hline \multicolumn{7}{|c|}{ Portland Cement Type I w/Sodium Sulfide } \\
\hline $8-1$ & 4.09 & 7.82 & 166.4 & 13.1 & 103 & 1.62 \\
\hline $8-2$ & 4.09 & 7.85 & 165.7 & 13.1 & 103 & 1.61 \\
\hline $8-3$ & 4.09 & 7.82 & 168 & 13.1 & 103 & 1.63 \\
\hline avg. & 4.09 & 7.83 & 166.7 & 13.1 & 103 & 1.62 \\
\hline std. dev. & 0.00 & 0.01 & 1.0 & 0.0 & 0.16 & 0.01 \\
\hline
\end{tabular}




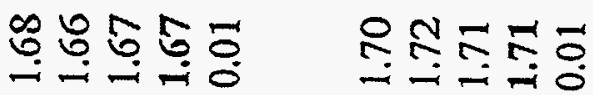

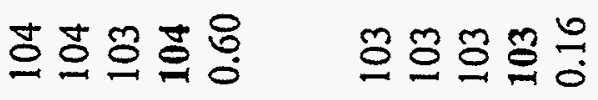

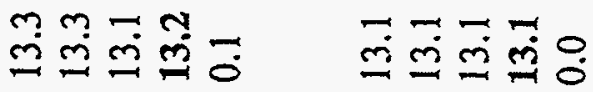

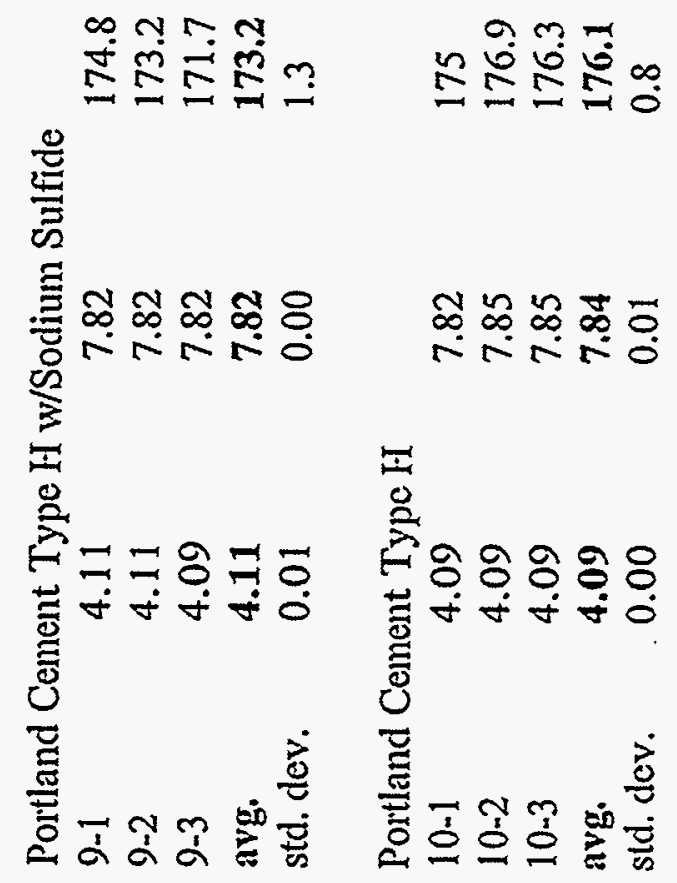

